\title{
We kunnen dus wel conclusies trekken over dus!
}

\begin{abstract}
Respondent Gert De Sutter plaatst mijn onderzoek in een rijtje klinkende namen (Diessel, Bresnan, Arnold). Eervol, maar tegelijkertijd plaatst hij een voorbehoud bij mijn conclusies. Graag maak ik van de gelegenheid gebruik om mij te verweren tegen de drie centrale kritiekpunten in zijn respons: 1) mijn (ontbrekende) definitie van de term discourse marker, 2) de wijze van sampling in mijn corpusonderzoek en 3 ) het nut en de noodzaak van diachroon onderzoek voor het blootleggen van vorm-betekenis-relaties.
\end{abstract}

\section{Discourse marker in theorie en praktijk}

Om maar met de deur in huis te vallen: eerlijk gezegd heb ik bewust vermeden om uitgebreid stil te staan bij een definitie van de term discourse marker. Zoals Schourup (1999: 228) ruim tien jaar geleden al opmerkte, is er namelijk "ondanks de hoeveelheid onderzoek op dit gebied [= naar discourse markers, JEV] (...) geen consensus over fundamentele zaken zoals terminologie en classificatie." Diane Blakemore (2002:1) trekt hieruit zelfs de extreme conclusie dat discourse markers als aparte categorie niet bestaan en dat we dus moeten stoppen om ze als zodanig te bestuderen (maar zie Bordería 2008 voor een reactie hierop).

Gezien de beschikbare ruimte lijkt het me niet haalbaar of wenselijk om hier alsnog een volledige definitie te geven. Ik wil volstaan met te zeggen dat ik de term connectief gereserveerd heb voor woorden die een lokale coherentierelatie tussen twee zinnen markeren; de term discourse marker heb ik voorbehouden aan markeerders op een globaler en/of interactioneel niveau, waarbij accessibility markers een subklasse binnen deze laatste categorie vormen. Mijn theoretische benadering verschilt van die van Fraser (2006: 189190), die de termen connectief en discourse marker als synoniemen behandelt.

Dat ik in de onderzoekspraktijk geen interbeoordelaarsbetrouwbaarheid heb gerapporteerd, is hierbij waarschijnlijk minder problematisch dan De Sutter suggereert. Ten eerste is er over de interpretatie van fragmenten veelvuldig overlegd met Ninke Stukker, die tijdens de analyses mijn collega was en die in haar dissertatie eveneens bevindingen over dus rapporteert (Stukker 2005). Aangezien meerdere interpretaties in overleg tot stand gekomen zijn, was het echter niet mogelijk om de betrouwbaarheidsanalyses los te laten op onze oordelen. Ik ben het met De Sutter eens dat het mooier zou zijn als ik dat wel had kunnen doen, maar dan wordt een tweede verweerpunt relevant. Spooren en 
Degand (in druk) laten namelijk zien dat het bij het coderen van coherentierelaties (en andere linguïstische fenomenen waar interpretaties centraal staan) bijna onmogelijk is om aan de hoge betrouwbaarheidsnorm te voldoen die doorgaans gesteld wordt $(\alpha=0,8)$. Dit betekent echter niet dat dergelijk onderzoek meteen niet valide is. Eventuele verschillen tussen beoordelaars hoeven namelijk niet per definitie codeerfouten te impliceren, maar kunnen ook ontstaan door de ambiguïteit die inherent is aan taalgebruik (zie in het geval van coherentierelaties bijvoorbeeld het fenomeen onderspecificatie, zoals besproken in Spooren 1997). Het is overigens aannemelijk dat een onderzoeker op een vrij systematische manier met deze ambiguïteit zal omgaan en dat daarmee - ook al is er maar één beoordelaar - niet meteen significante verschillen tussen periodes zullen ontstaan door de interpretaties die de onderzoeker toekent aan de fragmenten.

\section{Steekproeven en generaliseerbaarheid}

Met de tweedeling rijmende/literaire teksten versus niet-rijmende/niet-literaire teksten in mijn steekproeven heb ik proberen aan te sluiten bij een redelijk gangbare tweedeling in taalhistorisch onderzoek. ${ }^{1}$ Gert De Sutter geeft terecht aan dat er op basis van deze steekproeven niet gegeneraliseerd kan worden over specifieke genres of regio's; daarvoor is mijn steekproef te klein en had ik op een uitgebreidere manier moeten garanderen dat verschillende genres en regio's in mijn corpus vertegenwoordigd zouden zijn. Zoals zijn exploratieve analyse van dus in het Corpus Gesproken Nederlands en het Condiv-corpus Geschreven Nederlands uitwijst, is het heel goed denkbaar dat er meer factoren zijn die van invloed zijn op de plaatsing van dus.

Dat generaliseren over genres en regio's niet kan, wil niet zeggen dat generaliseren naar het taalgebruik in de drie bestudeerde periodes onmogelijk is. Ook al is er waarschijnlijk een verfijnder model denkbaar als verklaring voor het distributiepatroon van $d u s$, ik heb met mijn onderzoek wel degelijk laten zien dat de plaatsing van dus (mede) bepaald wordt door bijvoorbeeld de toegankelijkheid van de informatie in de dus-zin. Dat ik hiervoor een steekproef in plaats van alle dus-fragmenten heb geanalyseerd, doet hier niets aan af. Ter vergelijking: als Maurice de Hond voorspellingen doet over het stemgedrag van de Nederlanders, gaat hij ook niet aan alle Nederlanders vragen op wie ze zouden stemmen. Hij volstaat met een steekproef en kan op basis daarvan voorspellingen doen die altijd behoorlijk precies blijken te zijn. Doorgaans wordt er dan niet meteen op voorhand al gezegd dat het - vanwege deze werkwijze - schort aan de representativiteit. Het idee achter wetenschappelijk onderzoek aan de hand van steekproeven is juist dat je - door een random steekproef te trekken - met een beperktere hoeveelheid werk toch uitspraken kunt doen over alle voorkomens. De omvang van de steekproef had wat groter kunnen zijn, maar ik ben het dus niet met De Sutter eens dat het gebruik van een steekproef op zich fout is. Het is bovendien niet reëel om te verwachten dat een onderzoeker altijd alle attestaties zou onderzoeken wanneer elk fragment apart op inhoudelijke gronden beoordeeld moet worden (en automatische analyse dus niet mogelijk is).

1 Zie Evers-Vermeul (2005) voor een volledig overzicht van de teksten die in dit onderzoek gebruikt zijn en een verdere motivering voor deze tweedeling. 


\section{Nut en noodzaak van diachroon onderzoek}

Om op het derde en laatste punt in te gaan: ik vind diachroon onderzoek wel nuttig, maar niet noodzakelijk voor het opsporen van vorm-functie-interacties. Zoals de studies van Jansen en van Grondelaers uit de 2009-editie van Nederlandse Taalkunde duidelijk maken, is het zeker mogelijk om dergelijke interacties enkel te achterhalen aan de hand van synchrone data.

Toch ben het ik niet met De Sutter eens dat het logischer zou zijn om eerst te komen tot "een objectief, goed gevalideerd verklarend model van dus-plaatsing in hedendaags Nederlands". Dit veronderstelt namelijk dat de onderzoeker al vrij zeker weet welke factoren mogelijk relevant zijn om dit verklarende model samen te stellen. Het is echter goed denkbaar dat een onderzoeker - zoals in mijn geval - veel exploratiever te werk gaat en daarbij "ontwikkelingsdata" gebruikt om zich een eerste beeld te vormen van mogelijke invloedrijke factoren. Als er immers een samenhang bestaat tussen vorm A en betekenis $\mathrm{B}$, en als vorm A een bepaalde ontwikkeling vertoont, dan is het aannemelijk dat er ook iets zal veranderen in het gebruik van betekenis B.

De geschiktheid van taaldata "in ontwikkeling" voor het achterhalen van vormfunctierelaties is overigens niet alleen betoogd voor diachrone data (Cuenca 1997), maar ook voor kindertaaldata. Zoals Byrnes \& Gelman (1991: 4) het verwoorden: "een ontwikkelingsbenadering betreft inherent een proces, en is dus uitermate geschikt om relaties tussen de ingrediënten van een complex systeem op te sporen". Mijns inziens kun je diachrone data dus zowel als eindpunt gebruiken, als aanvulling op een eerdere synchrone analyse, maar zeker ook als startpunt voor een uitgebreidere synchrone analyse. In het geval van dus moet die er zeker nog komen, en ik ben ervan overtuigd dat mijn diachrone studie bruikbare en valide aanknopingspunten biedt voor een dergelijk onderzoek, waarin ook stilistische en regionale factoren verder uitgediept kunnen worden. 